\title{
Karakteristik dan Kesintasan Penyakit Ginjal Kronik Stadium 3 dan 4 pada Anak di Departemen IImu Kesehatan Anak FKUI-RSCM
}

\author{
Swanty Chunnaedy, Sudung O Pardede, Mulyadi M. Djer \\ Departemen Ilmu Kesehatan Anak Fakultas Kedokteran Universitas Indonesia/Rumah Sakit Dr. Cipto \\ Mangunkusumo, Jakarta
}

\begin{abstract}
Latar belakang. Penyakit ginjal kronik merupakan terminologi baru untuk pasien yang mengalami kerusakan ginjal paling sedikit selama tiga bulan dengan atau tanpa penurunan LFG. Terminologi ini belum banyak digunakan di Indonesia sehingga karakteristik dan kesintasan PGK stadium 3 dan 4 pada anak belum banyak diteliti.

Tujuan. Mendapatkan karakteristik dan kesintasan PGK stadium 3 dan 4 pada anak yang berobat di Departemen Ilmu Kesehatan Anak FKUI-RSCM

Metode. Penelitian kohort prospektif historikal ini diambil dari rekam medis pasien dengan PGK stadium 3 dan 4 menurut kiriteria NKF KDOQI di Departemen Ilmu Kesehatan Anak FKUI-RSCM sejak Januari 2004 hingga 30 November 2012. Kesintasan dianalisis dengan menggunakan Kaplan Meier dengan event yang dinilai adalah PGK stadium 5 atau kematian.

Hasil. Terdapat 50 rekam medis yang masuk dalam analisis, terdiri atas 36 subjek PGK stadium 3 dan 14 subjek PGK stadium 4. Median usia adalah 7,9 (2-15) tahun dengan jenis kelamin perempuan (58\%) sedikit lebih banyak dari pada laki-laki (42\%). Etiologi terbanyak adalah glomerulonefritis (56\%) dengan sindrom nefrotik memiliki proporsi terbesar. Gambaran klinis yang ditemukan adalah hipertensi (42\%), gizi kurang $(40 \%)$, anemia $(70 \%)$, gangguan elektrolit $(78 \%)$, asidosis $(34 \%)$, proteinuria $(72 \%)$, perawakan pendek (56\%), osteodistrofi renal (2\%), dan kardiomiopati dilatasi (14\%). Median kesintasan keseluruhan adalah 57,13 bulan (IK 95\% 11,18 sampai 103,09).

Kesimpulan. Penyakit ginjal kronik stadium 3 dan 4 sedikit lebih banyak terjadi pada perempuan dengan etiologi terbanyak adalah glomerulonefritis. Komplikasi yang paling sering adalah gangguan elektrolit, anemia, perawakan pendek, gizi kurang, dan hipertensi. Median kesintasan keseluruhan adalah 57,13 bulan (IK $95 \%$ 11,18 sampai 103,09). Sari Pediatri 2014;16(2):71-8.
\end{abstract}

Kata kunci: penyakit ginjal kronik, anak, kesintasan

Alamat korespondensi:

Dr. Swanty Chunnaedy, SpA. BRSUD 45 Kuningan. Jl. Jend Sudirman No. 68, Kuningan, Jakarta Barat 45511.Telp. (0232) 871885. E-mail: swanty_cun@idai.or.id,swanty_cun@yahoo.com

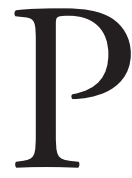
enyakit ginjal kronik (PGK) merupakan terminologi baru yang dikeluarkan oleh the National Kidney Foundation's Kidney Disease and Outcome Quality Initiative (NKF 
KDOQI) pada bulan Februari tahun 2002 untuk mengelompokkan setiap pasien yang mengalami kerusakan ginjal paling sedikit selama tiga bulan dengan atau tanpa penurunan LFG atau pasien yang memiliki LFG $<60 \mathrm{~mL} /$ menit $/ 1,73 \mathrm{~m}^{2}$ lebih dari tiga bulan dengan atau tanpa kerusakan ginjal., ${ }^{1,2}$ Morbiditas dan mortalitas yang meningkat disebabkan PGK serta masalah sosial ekonomi yang cukup signifikan. Kerusakan ginjal terjadi sejak PGK stadium I dan II, tetapi biasanya asimtomatis. Komplikasi mulai muncul pada LFG $<60 \mathrm{~mL} /$ menit $/ 1,73 \mathrm{~m}^{2}$ (PGK stadium 3), meliputi komplikasi kardiovaskular, anemia, malnutrisi, hipertensi, dan penyakit tulang. Kegagalan fungsi ginjal dan komplikasi kardiovaskular merupakan penyebab kematian utama pada PGK. ${ }^{3}$ Progresivitas penyakit ditentukan oleh beberapa faktor risiko, seperti hipertensi, proteinuria, anemia, genetik, ras, usia, dan jenis kelamin. ${ }^{4}$ Penelitian Soares $\mathrm{dkk}^{5}$ menunjukkan bahwa probabilitas pasien anak yang menderita PGK dengan LFG $\leq 75 \mathrm{~mL} / \mathrm{menit} / 1,73 \mathrm{~m}^{2}$ menjadi PGK stadium 5 sebesar $36 \%$ setelah 5 tahun didiagnosis PGK. Rata-rata penurunan LFG sebesar $5,8 \mathrm{~mL} /$ menit $/ 1,73 \mathrm{~m}^{2}$ tiap tahunnya.

Di Indonesia, terminologi PGK masih jarang digunakan sehingga profil klinisnya belum banyak diketahui. Progresivitas PGK stadium awal menjadi stadium 5 atau meninggal belum pernah diteliti sehingga penelitian ini bertujuan untuk mengetahui karakteristik dan kesintasan PGK pada anak dengan PGK stadium 3 dan 4 di Departemen Ilmu Kesehatan Anak Fakultas Kedokteran Universitas IndonesiaRumah Sakit Cipto Mangunkusumo (IKA FKUIRSCM) sehingga dapat diketahui prognosis penyakit dengan tata laksana yang sudah ada.

\section{Metode}

Desain penelitian kohort prospektif historikal yang diambil dari rekam medis di Departemen IKA FKUIRSCM sejak Januari 2004 hingga 30 November 2012, kemudian diamati luaran akhirnya sampai penelitian dinyatakan selesai. Kriteria pemilihan subjek meliputi usia 2-18 tahun dan memenuhi kriteria PGK stadium 3 dan 4 menurut NKF KDOQI. Data diolah dengan menggunakan SPSS versi 17. Data ditabulasi untuk melihat karakteristik subjek. Kesintasan dianalisis dengan menggunakan Kaplan Meier dengan event yang dinilai adalah PGK stadium 5 atau kematian.

\section{Hasil}

Dalam kurun waktu 8 tahun, didapatkan 77 rekam medis pasien di Departemen IKA FKUI-RSCM yang memiliki LFG 15-60 mL/menit/1,73 $\mathrm{m}^{2}$. Dalam pengamatan, 27 pasien mengalami perbaikan LFG sehingga dieksklusi. Lima puluh subjek diikutsertakan dalam penelitian (Gambar 1). Dari 30 rekam medis yang diketahui luaran akhirnya, 4 pasien meninggal di RSCM, 11 pasien progresif menjadi PGK stadium 5 (3 di antaranya meninggal baik di RSCM maupun di rumah), dan 15 pasien kontrol rutin di Departemen IKA FKUI-RSCM dengan fungsi ginjal yang relatif tidak berubah.

Dua puluh subjek penelitian tidak diketahui luaran akhirnya melalui rekam medis. Duabelas pasien berhasil diketahui statusnya baik melalui penelusuran ke rumah pasien maupun lewat telepon, yaitu 5 pasien meninggal; 2 pasien hidup, tetapi pindah keluar kota; 4 pasien hidup, tetapi menolak memeriksakan fungsi ginjalnya; 1 pasien masih rutin kontrol di Departemen Ilmu Penyakit Dalam FKUI-RSCM dengan fungsi ginjal yang relatif sama. Delapan pasien lainnya tidak dapat ditelusuri karena beberapa alasan, yaitu pasien pindah rumah, nomor telepon yang dihubungi tidak aktif, atau pasien berada di luar kota.

Dua puluh sembilan pasien berjenis kelamin perempuan (58\%). Median usia adalah 7,9 (2-15) tahun dengan median lama pengamatan 15,3 (0,07159,3) bulan. Etiologi PGK paling banyak adalah glomerulonefritis (56\%) dengan sindrom nefrotik memiliki proporsi terbesar, diikuti dengan nefritis

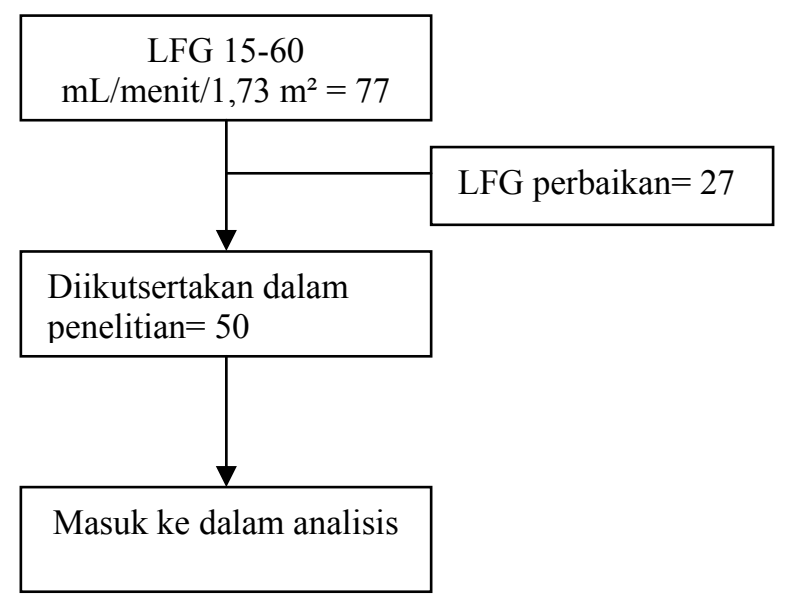

Gambar 1. Hasil penelusuran rekam medis 
lupus. Pasien yang datang dengan stadium $3(72 \%)$ lebih banyak dibandingkan stadium 4 (28\%). Karakteristik dasar subjek penelitian tertera pada Tabel 1. sudah terdiagnosis PGK stadium 3 ataupun 4 sejak tahun tersebut di atas, tetapi masih kontrol teratur di Departemen IKA FKUI-RSCM.

Hipertensi terjadi pada $42 \%$ pasien, yaitu $14 \%$

Tabel 1. Karakteristik dasar pasien anak dengan PGK stadium 3 dan 4

\begin{tabular}{lc}
\hline Karakteristik & $\begin{array}{c}\text { Jumlah } \\
\mathrm{n}=50\end{array}$ \\
\hline Jenis kelamin (n (\%)) & $21(42)$ \\
Laki-laki & $29(58)$ \\
Perempuan & \\
Etiologi (n (\%)) & $28(56)$ \\
Glomerulonefritis & $18(36)$ \\
Sindrom nefrotik & $7(14)$ \\
Nefritis lupus & $3(6)$ \\
Glomerulonefritis kronik & $4(8)$ \\
Pyelonefritis kronik & $4(8)$ \\
Neurogenic bladder & $4(8)$ \\
Kelainan kongenital & $3(6)$ \\
Keganasan & $7(14)$ \\
Lain-lain & $36(72)$ \\
Stadium PGK (n (\%)) & $14(28)$ \\
Stadium 3 & \\
Stadium 4 & $(15,45-60) \mathrm{mL} / \mathrm{menit} / 1,73 \mathrm{~m}^{2}$ \\
LFG saat terdiagnosis (median (rentang)) & $7,9(2-15)$ tahun \\
Usia saat terdiagnosis (median (rentang)) & $15,3(0,07-159,5)$ bulan \\
Lama pengamatan (median (rentang)) &
\end{tabular}

Gambar 2 menunjukkan sebaran kejadian PGK stadium 3 dan 4 berdasarkan tahun masuk. Grafik ini menunjukkan peningkatan kejadian PGK stadium 3 dan 4 dari tahun ke tahun. Penelusuran direncanakan terhadap rekam medis sejak tahun 2004 sampai 2012, tetapi ditemukan pasien yang masuk pada tahun 1999 dan 2001. Hal tersebut dikarenakan pasien

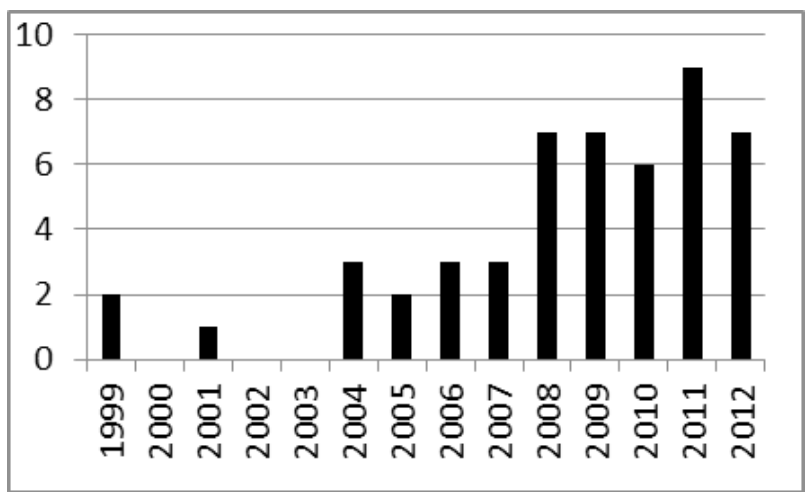

Gambar 2. Sebaran kejadian PGK stadium 3 dan 4 berdasarkan tahun masuk hipertensi derajat 1 dan 28\% hipertensi derajat 2. Gizi buruk tidak ditemukan, $46 \%$ gizi baik dan $46 \%$ gizi kurang. Kejadian anemia $70 \%$ pasien dengan rata-rata kadar hemoglobin 10,10 g/dL. Kejadian gangguan elektrolit $78 \%$ pasien, baik hiponatremia, hipokalemia, hiperkloremia, hipokalsemia, hipofosfatemia, maupun hiperfosfatemia. Pasien yang datang dengan PGK stadium 3 dan 4 tidak semua diperiksa kadar elektrolit secara lengkap. Semua elektrolit tidak diperiksakan pada $10 \%$ pasien, sementara kadar kalsium dan kadar fosfat tidak diperiksakan secara berturut-turut pada $40 \%$ dan $66 \%$ pasien. Asidosis dialami 34\% pasien, tetapi analisis gas darah tidak diperiksa pada $36 \%$ pasien. Sebanyak $72 \%$ pasien mengalami proteinuria. Komplikasi PGK seperti perawakan pendek, pubertas terlambat, osteodistrofi renal dan kardiomiopati dilatasi terjadi secara berturut-turut pada 56\%, 6\%, 2\%, dan $14 \%$ pasien. Gambaran klinis PGK yang muncul pada subjek penelitian tertera pada Tabel 2 .

Duapuluh pasien PGK stadium 3 dan 4 mengalami event (progresif menjadi stadium 5 atau kematian), terdiri atas 14 pasien stadium 3 dan 6 pasien stadium 
4. Tujuh pasien dengan PGK stadium 3 progresif menjadi stadium 5, dan 3 di antaranya meninggal dunia. Sepuluh pasien PGK stadium 3 dan 2 pasien stadium 4 meninggal dunia, serta 4 pasien progresif menjadi stadium 5 . Penyebab kematian pasien adalah sindrom uremikum, asidosis metabolik berat, syok sepsis, syok hipovolemik, dan sebab yang tidak diketahui karena pasien meninggal di rumah. Median kesintasan keseluruhan pasien PGK stadium 3 dan 4 adalah 57,13 bulan (IK 95\% 11,18 sampai 103,09) (Gambar 3).

Tabel 2. Gambaran klinis anak dengan PGK Stadium 3 dan 4

\begin{tabular}{|c|c|c|c|}
\hline Gambaran klinis & $\begin{array}{c}\text { PGK stadium } 3 \\
\mathrm{n}=36\end{array}$ & $\begin{array}{c}\text { PGK stadium } 4 \\
\mathrm{n}=14\end{array}$ & $\begin{array}{c}\text { PGK stadium 3-4 } \\
n=50\end{array}$ \\
\hline \multicolumn{4}{|l|}{ Hipertensi (n (\%)) } \\
\hline Tidak hipertensi & $21(58,3)$ & $8(57,1)$ & $29(58)$ \\
\hline Hipertensi derajat 1 & $5(13,9)$ & $2(14,3)$ & $7(14)$ \\
\hline Hipertensi derajat 2 & $10(27,8)$ & $4(28,6)$ & $14(28)$ \\
\hline \multicolumn{4}{|l|}{ Status nutrisi (n (\%)) } \\
\hline Baik & $18(50)$ & $5(35,7)$ & $23(46)$ \\
\hline Kurang & $15(41,7)$ & $8(57,1)$ & $23(46)$ \\
\hline Lebih & $0(0)$ & $1(7,1)$ & $1(2)$ \\
\hline Obesitas & $3(8,3)$ & $0(0)$ & $3(6)$ \\
\hline Anemia (n (\%)) & $22(61,1)$ & $13(92,9)$ & $35(70)$ \\
\hline Gangguan elektrolit (n (\%)) & & & $39(78)$ \\
\hline \multicolumn{4}{|l|}{ Natrium } \\
\hline Hiponatremia & $12(33,3)$ & $4(28,6)$ & $16(32)$ \\
\hline Hipernatremia & $0(0)$ & $0(0)$ & $0(0)$ \\
\hline Tidak ada data & $9(25)$ & $1(7,1)$ & $10(20)$ \\
\hline \multicolumn{4}{|l|}{ Kalium } \\
\hline Hipokalemia & $7(19,4)$ & $1(7,1)$ & $8(16)$ \\
\hline Hiperkalemia & $2(5,6)$ & $4(28,6)$ & $6(12)$ \\
\hline Tidak ada data & $9(25)$ & $1(7,1)$ & $10(20)$ \\
\hline \multicolumn{4}{|l|}{ Klorida } \\
\hline Hipokloremia & $7(19,4)$ & $3(21,4)$ & $10(20)$ \\
\hline Hiperkloremia & $10(27,8)$ & $5(35,7)$ & $15(30)$ \\
\hline Tidak ada data & $11(10,36)$ & $1(7,1)$ & $12(24)$ \\
\hline \multicolumn{4}{|l|}{ Kalsium } \\
\hline Hipokalsemia & $12(33,3)$ & $9(64,3)$ & $21(42)$ \\
\hline Tidak ada data & $17(47,2)$ & $3(21,4)$ & $20(40)$ \\
\hline \multicolumn{4}{|l|}{ Fosfat } \\
\hline Hipofosfatemia & $5(13,9)$ & $0(0)$ & $5(10)$ \\
\hline Hiperfosfatemia & $5(13,9)$ & $4(28,6)$ & $9(18)$ \\
\hline Tidak ada data & $24(66,7)$ & $9(64,3)$ & $33(66)$ \\
\hline \multicolumn{4}{|l|}{ Derajat keasaman (n (\%)) } \\
\hline Asidosis & $10(27,8)$ & $7(50)$ & $17(34)$ \\
\hline Alkalosis & $6(16,6)$ & $2(14,3)$ & $8(16)$ \\
\hline Tidak ada data & $15(41,7)$ & $3(21,4)$ & $18(36)$ \\
\hline \multicolumn{4}{|l|}{ Proteinuria (n (\%)) } \\
\hline+1 & $5(13,9)$ & $4(28,6)$ & $9(18)$ \\
\hline+2 & $7(19,4)$ & $4(28,6)$ & $11(22)$ \\
\hline+3 & $12(33,3)$ & $4(28,6)$ & $16(32)$ \\
\hline Tidak ada data & $5(13,9)$ & $1(7,1)$ & $6(12)$ \\
\hline Perawakan pendek (n (\%)) & $21(58,3)$ & $7(50)$ & $28(56)$ \\
\hline Pubertas terlambat (n (\%)) & $3(8,3)$ & $0(0)$ & $3(6)$ \\
\hline Osteodistrofi renal (n (\%)) & $1(2,7)$ & $0(0)$ & $1(2)$ \\
\hline Kardiomiopati dilatasi (n (\%)) & $4(11,1)$ & $3(21,4)$ & $7(14)$ \\
\hline
\end{tabular}




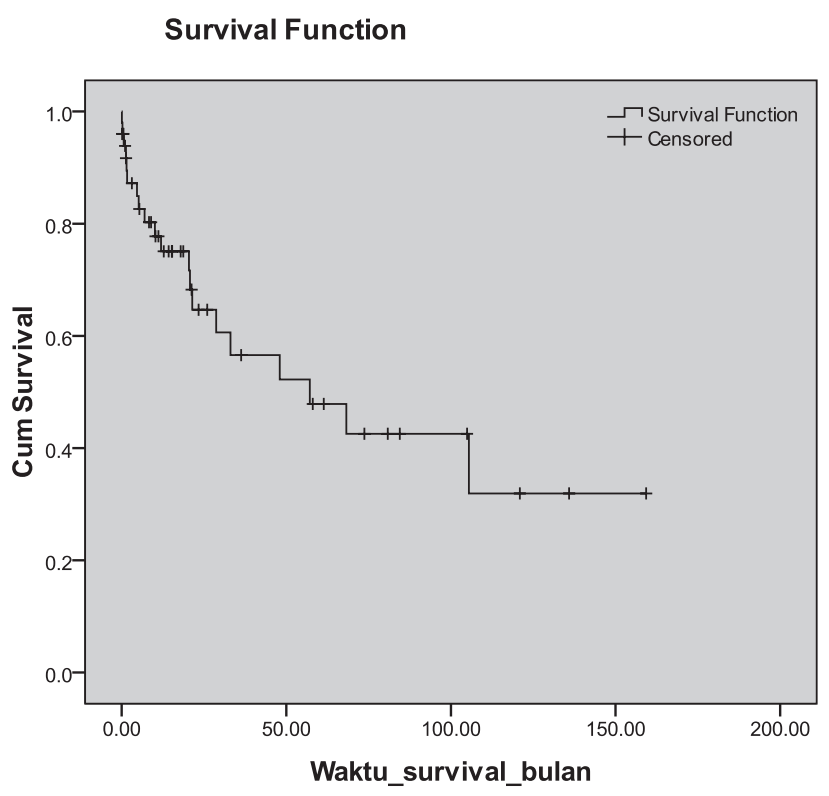

Gambar 3. Kurva Kaplan Meier kesintasan keseluruhan pasien PGK Stadium 3 dan 4

\section{Pembahasan}

Pada penelitian ini, 58\% subjek berjenis kelamin perempuan dengan rasio laki-laki perempuan adalah 1:1,4. Hasil penelitian ini berbeda dengan penelitian sebelumnya. Penelitian yang dilakukan oleh Soares $\mathrm{dkk}^{5}$ menunjukkan laki-laki (53,3\%) lebih banyak dari perempuan $(46,7 \%)$. Penelitian yang dilakukan oleh Ahmadzadeh $\mathrm{dkk}^{6}$ juga menunjukkan hasil yang hampir serupa, yaitu laki-laki $(58,2 \%)$ lebih banyak dari pada perempuan (42,8\%). Hal tersebut disebabkan oleh bias seleksi pada penelitian ini. Glomerulonefritis (56\%) merupakan etiologi terbanyak PGK stadium 3 dan 4 di Poliklinik Nefrologi Departemen IKA FKUIRSCM dengan sindrom nefrotik sebagai komponen terbanyak, yaitu 36\% dari total subjek. Kelainan kongenital dan neurogenic bladder hanya ditemukan pada masing-masing $7 \%$ subjek. Hal tersebut hampir sama dengan penelitian yang dilakukan oleh Gheissari $\mathrm{dkk}^{7}$ yang menyebutkan sindrom nefrotik $(19,4 \%)$ sebagai etiologi PGK terbanyak pada populasi penelitian mereka, diikuti dengan glomerulonefritis $(15,8 \%)$, dan refluks nefropati $(16,7 \%)$. Berbeda dengan penelitian ini, penelitian Italkid $^{8}$ menyebutkan hipodisplasia saluran kemih (57,5\%) sebagai etiologi terbanyak PGK, sedangkan sindrom nefrotik kongenital dan nefritis lupus terjadi pada masing-masing $1,1 \%$ dan $1,1 \%$. Soares $\mathrm{dkk}^{5}$ juga menyebutkan kelainan kongenital $(53,4 \%)$ sebagai penyebab terbanyak pada populasi mereka yang diikuti oleh penyakit glomerulus $(22,4 \%)$. Perbedaan tersebut mungkin terjadi karena RSCM merupakan rumah sakit rujukan nasional sehingga pasien yang dirujuk adalah terutama pasien dengan gejala klinis PGK yang jelas, misalnya edema. Hal tersebut juga disebabkan oleh kegagalan diagnosis dini kelainan kongenital pada anak yang jarang menunjukkan gejala yang jelas. Pada umumnya, pasien dengan kelainan kongenital datang dengan infeksi saluran kemih yang sering kali tidak diikuti dengan pemeriksaan penunjang untuk mencari kelainan yang mendasari.?

Data epidemiologi PGK, terutama PGK stadium awal pada anak, sampai saat ini belum banyak dilaporkan karena PGK stadium awal sering asimtomatis dan tidak terdiagnosis. ${ }^{10}$ Kejadian PGK stadium 3 dan 4 di Departemen IKA FKUI-RSCM mencapai 50 kasus selama 8 tahun terakhir. Hal tersebut hampir sama dengan penelitian Soares $\mathrm{dkk}^{5}$ di Brazil yang menemukan 107 kasus PGK dengan LFG <75 $\mathrm{mL} /$ menit $/ 1,73 \mathrm{~m}^{2}$ dalam kurun waktu 15 tahun. Penelitian Hidayati dkk ${ }^{9}$ menyebutkan PGK stadium 3 dan 4 mencapai 20\% dan 8\% dari seluruh PGK di Departemen IKA FKUI RSCM selama periode tersebut, sedangkan PGK stadium 5 mencapai 29\%. Kejadian PGK stadium 5 yang tinggi pada penelitian Hidayati dkk, menunjukkan kesadaran masyarakat dan tenaga kesehatan yang rendah dalam deteksi dini PGK.

Kejadian PGK stadium 3 dan 4 di Departemen IKA FKUI-RSCM meningkat dari tahun ke tahun. Temuan tersebut sama dengan penelitian Vachvanichsanong dkk $^{11}$ di Thailand, menggambarkan peningkatan 2 kali lipat dalam dua periode 6 tahunan, yaitu 33 kejadian pada periode 1994-1999 dan 65 kejadian pada periode 2000-2005. Peningkatan kejadian PGK di Thailand diperkirakan karena banyak kasus PGK yang tidak terdiagnosis sebelumnya berkaitan dengan kesadaran yang kurang tentang PGK pada anak. Indonesia merupakan negara berkembang yang hampir serupa dengan Thailand dan mengalami kendala yang hampir sama dalam menghadapi PGK pada anak. Sebelum PGK disosialisasikan secara luas, pemeriksaan fungsi ginjal pada anak yang mengalami masalah di bidang nefrologi baik pada saat datang pertama kali maupun selama pemantauan belum rutin dikerjakan. Pada penelitian ini, peningkatan angka kejadian PGK 
stadium 3 dan 4 masih mungkin karena banyaknya kasus PGK yang tidak terdiagnosis sebelumnya.

Usia saat terdiagnosis PGK stadium 3 dan 4 adalah 7,9 (2-15) tahun, hampir sama dengan penelitian Soares $\mathrm{dkk}^{5}$ yaitu 8,3 tahun. Hipertensi dialami $42 \%$ pasien, yaitu $14 \%$ hipertensi derajat 1 dan $28 \%$ derajat 2. Hal tersebut tidak jauh berbeda dengan penelitian Staples $\mathrm{dkk}^{12}$ pada 6133 anak dengan PGK stadium 2 sampai 4. Pada penelitian tersebut, hipertensi terjadi pada 46,9\% subjek. Demikian pula dengan penelitian Soares dkk, ${ }^{5}$ hipertensi terjadi pada $45 \%$ subjek. Hipertensi merupakan gejala yang sering ditemukan pada PGK dan merupakan faktor prediktor progresivitas PGK pada anak karena hipertensi dapat menyebabkan perburukan fungsi ginjal dan komplikasi kardiovaskular. ${ }^{13,14}$ Komplikasi kardiovaskular menyebabkan 20\%-25\% kematian pada PGK, terutama kardiomiopati dilatasi. ${ }^{15}$ Pada penelitian ini, kardiomiopati dilatasi terjadi pada 14 $\%$ subjek penelitian, dua orang di antaranya meninggal dunia.

Empatpuluh enam persen subjek penelitian mengalami gizi kurang dan 56\% perawakan pendek, sedangkan gizi buruk tidak ditemukan. Berbeda dengan penelitian ini, Soares $\mathrm{dkk}^{5}$ menyebutkan gangguan pertumbuhan ditemukan $25,5 \%$ pada saat diagnosis pertama kali dan menjadi $46 \%$ pada akhir pengamatan. Berdasarkan data North American Pediatric Renal Transplant Cooperative Study (NAPRTCS), ${ }^{16}$ periode Januari 1994 sampai Januari 2004, kejadian perawakan pendek pada anak dengan $\mathrm{LFG} \leq 75 \mathrm{~mL} / \mathrm{menit} / 1,73 \mathrm{~m}^{2}$ adalah $36,9 \%$. Penelitian lain oleh Wong dkk, ${ }^{17}$ pada 366 anak dengan PGK, ditunjukkan bahwa prevalensi perawakan pendek pada PGK stadium 3 adalah 10,53\% serta pada PGK stadium 4 dan 5 adalah 13,33\%. Komplikasi PGK lain adalah anemia. Pada penelitian ini, anemia terjadi pada $70 \%$ subjek penelitian, yaitu pada 22 pasien dengan PGK stadium 3 dan 13 pasien stadium 4. Penelitian kohort retrospektif oleh Staples dkk, ${ }^{12}$ pada 4166 anak dengan PGK stadium 2 sampai 4, ditunjukkan bahwa 37,9\% pasien mengalami anemia. Prevalensi anemia pada penelitian Wong $\mathrm{dkk}^{17}$ lebih mendekati hasil penelitian ini, yaitu 65,8\% pada PGK stadium 3 dan $93,3 \%$ pada PGK stadium 4 dan 5 . Kejadian gizi kurang, perawakan pendek, dan anemia yang cukup tinggi dapat memengaruhi status sosial ekonomi dan pola pemberian makanan yang kurang baik seperti yang digambarkan oleh laporan hasil riset kesehatan dasar (Riskesdas) tahun 2007 dan 2010. ${ }^{18}$ Prevalensi perawakan pendek dan gizi kurang balita secara nasional pada tahun 2010 mencapai 35,6\% dan 13\%. Pada anak di DKI Jakarta, prevalensi anemia sebesar 18,6\% menurut laporan Riskesdas tahun $2007 .{ }^{19}$

Gangguan elektrolit terjadi pada $78 \%$ pasien. Duabelas pasien mengalami hiperkalemia, yaitu terjadi pada 5,6\% PGK stadium 3 dan 28,6\% stadium 4. Asidosis terjadi pada 27,8\% PGK stadium 3 dan 50\% PGK stadium 4. Hasil tersebut tidak jauh berbeda dengan penelitian Wong dkk, hiperkalemia terjadi pada 5,26\% PGK stadium 3 serta 18,18\% PGK stadium 4 dan 5. Demikian pula dengan angka kejadian asidosis pada penelitian ini hampir menyerupai penelitian Wong dkk, yaitu 54,55\% PGK stadium 4 dan 5, tetapi pada stadium 3 hasil temuan Wong jauh lebih rendah, yaitu $7,89 \% .{ }^{17}$ Pada penelitian ini, hipokalsemia dan hiperfosfatemia terjadi secara berturut-turut pada $42 \%$ dan $18 \%$ subjek. Staples $\mathrm{dkk}^{12}$ melaporkan kejadian hipokalsemia yang jauh lebih rendah, yaitu 5,1\% dan hiperfosfatemia yang lebih tinggi, yaitu $28,3 \%$. Perbedaan tersebut dapat disebabkan oleh banyaknya pasien yang tidak diperiksa kadar elektrolit dan analisis gas darah pada saat diagnosis awal. Empatpuluh persen dan $66 \%$ subjek tidak diperiksa kalsium dan fosfat, sedangkan analisis gas darah tidak diperiksakan pada $36 \%$ subjek.

Kalsium dan fosfat merupakan elektrolit yang penting dipantau karena berhubungan dengan mineralisasi tulang. Osteodistrofi renal merupakan komplikasi PGK yang timbul akibat gangguan metabolisme kalsium, fosfat, dan vitamin D. ${ }^{20}$ Pada penelitian ini, osteodistrofi renal ditemukan pada satu subjek. Osteodistrofi renal pada subjek penelitian masih mungkin belum terdiagnosis karena sering asimtomatis dan baru bergejala setelah tahap lanjut. Gejala yang muncul sering tidak khas seperti nyeri, kekakuan pada sendi, ruptur tendon spontan, dan kelemahan otot. ${ }^{21}$

Proteinuria merupakan petanda dan faktor risiko kerusakan ginjal. The National Kidney Foundation's Kidney Disease and Outcome Quality Initiative merekomendasikan pemeriksaan protein urin total sebagai uji tapis penyakit ginjal kronik pada anak. ${ }^{22}$ Soares $\mathrm{dkk}^{5}$ menemukan bahwa anak dengan proteinuria berat memiliki median penurunan LFG enam kali lebih besar daripada anak tanpa proteinuria. Pada penelitian ini, proteinuria ditemukan $72 \%$ pasien, lebih tinggi dibanding penelitian Wong dkk yang 
menyebutkan bahwa proteinuria terjadi pada $62 \%$ pasien. Perbedaan tersebut terjadi kemungkinan karena penelitian Wong dkk memasukkan semua pasien anak dengan LFG 30 sampai $90 \mathrm{~mL} /$ menit $/ 1,73 \mathrm{~m}^{2}$ dengan desain penelitian potong lintang dan 54\% pasien sudah mendapatkan terapi ACE inhibitors dan ARBs yang memiliki efek renoprotektif. ${ }^{23}$

Sebelas (22\%) pasien PGK stadium 3 dan 4 progresif menjadi stadium 5 dan pada akhir pengamatan terdapat 12 pasien meninggal dunia. Penelitian yang ada sampai saat ini menunjukkan hasil yang berbeda. Soares $\mathrm{dkk}^{5}$ menemukan 53\% pasien dengan LFG $<75$ $\mathrm{mL} /$ menit $/ 1,73 \mathrm{~m}^{2}$ progresif menjadi PGK stadium 5 , sedangkan penelitian Bhimma $\mathrm{dkk}^{24}$ menemukan bahwa terdapat 20 pasien dari 653 pasien PGK stadium 2-4 progresif menjadi stadium yang lebih lanjut, tetapi tidak ada satupun yang menjadi stadium 5. Loss to follow up penelitian Bhimma mencapai $40 \%$. Penelitian Hiep $^{25}$ di Belgia terhadap 143 pasien PGK stadium 3-5 ditunjukkan bahwa setelah 3, 4, dan 5 tahun pengamatan terdapat 27,31 , dan $38 \%$ pasien PGK stadium 3 dan 4 yang progresif menjadi stadium 5 . Terdapat 4 pasien meninggal selama pengamatan. Jika dibandingkan dengan penelitian Bhimma, penelitian ini memiliki angka loss to follow up yang lebih sedikit, yaitu 16\% sehingga masih mungkin angka kejadian pasien yang progresif menjadi stadium 5 pada penelitian Bhimma lebih banyak. Pada penelitian ini tidak dilakukan analisis progresivitas berdasarkan tahun pengamatan.

Pada penelitian ini, median kesintasan keseluruhan subjek adalah 57,13 bulan. Hal tersebut menunjukkan bahwa $50 \%$ subjek penelitian sudah mengalami event pada 57,13 bulan. Hasil tersebut hampir sama dengan penelitian Staples $\mathrm{dkk}^{12}$ yang menyebutkan bahwa median kesintasan keseluruhan PGK stadium 2, 3, dan 4 mencapai stadium 5 adalah 53,7 bulan. Penelitian tersebut merupakan studi kohort retrospektif yang diambil dari data the North American Renal Trials and Cooperative Studies CKD yang terdiri atas 4166 anak dengan PGK stadium 2 sampai 4. Penelitian Soares ${ }^{5}$ dkk menemukan probabilitas PGK dengan LFG $<75$ $\mathrm{mL} /$ menit $/ 1,73 \mathrm{~m}^{2}$ menjadi stadium 5 adalah $14 \%$ pada tahun pertama, 36\% tahun ke-5, dan 54\% tahun ke-10, dengan median kesintasan keseluruhan yang lebih panjang, yaitu 7,9 tahun. Perbedaan penelitian ini dengan penelitian Soares $\mathrm{dkk}$ adalah subjek penelitian Soares terdiri atas semua anak dengan LFG $<75 \mathrm{~mL} /$ menit/1,73 $\mathrm{m}^{2}$ (sesuai dengan PGK stadium 3 dan
4, serta sebagian PGK stadium 2), event yang diteliti adalah PGK stadium 5, median lama pengamatan 94 bulan, dan seluruh pasien dapat diamati sampai akhir penelitian, sedangkan pada penelitian ini event adalah stadium 5 dan kematian, median lama pengamatan 15,3 bulan dengan loss to follow up mencapai $16 \%$.

Keterbatasan penelitian ini adalah besar sampel yang tidak mencapai jumlah ideal dan kemungkinan bias seleksi akibat kesulitan menemukan rekam medis yang diperlukan. Loss to follow up mencapai 16\% karena pasien yang tidak diketahui luaran akhirnya sampai penelitian dinyatakan selesai tidak dapat ditelusuri, baik karena alamat yang tidak jelas, pindah alamat, ganti nomor telepon, maupun alamat yang sulit dijangkau. Diperlukan penelitian lebih lanjut dengan besar sampel yang lebih besar dan jumlah loss to follow up yang lebih sedikit untuk mengetahui karakteristik dan kesintasan PGK stadium 3 dan 4 pada anak.

\section{Kesimpulan}

Penyakit ginjal kronik stadium 3 dan 4 di Departemen IKA FKUI-RSCM lebih banyak terjadi pada perempuan $(58 \%)$ dengan etiologi terbanyak adalah glomerulonefritis (56\%). Komplikasi PGK di Departemen IKA FKUI-RSCM yang paling sering adalah gangguan elektrolit (78\%), anemia (70\%), perawakan pendek $(56 \%)$, gizi kurang $(46 \%)$, dan hipertensi (42\%). Median kesintasan keseluruhan PGK stadium 3 dan 4 adalah 57,13 bulan (IK $95 \%$ 11,18 sampai 103,09). Rentang interval kepercayaan yang cukup besar menunjukkan bahwa median kesintasan keseluruhan cukup heterogen sehingga diperlukan penelitian lanjutan untuk mengetahui median kesintasan keseluruhan PGK stadium 3 dan 4 yang dianalisis secara terpisah.

\section{Daftar pustaka}

1. NKF KDOQI. KDOQI clinical practice guidelines for chronic kidney disease: evaluation, classification, and stratification. (diakses 31 Mei 2009). Diunduh dari: www.kidney.org/professionals/kdoqi/guidelines_ckd.

2. Mak RH. Chronic kidney disease in children: state of the art. Pediatr Nephrol 2007;22:1687-8.

3. Weiner DE. Causes and consequences of chronic kidney disease: implication for managed health care. Managed 
Care Pharm 2007;3:S1-9.

4. Warady BA, Chadha V. Chronic kidney disease in children: the global perspective. Pediatr Nephrol 2007;22:1999-2009.

5. Soares CMB, Diniz JSS, Lima EM, Silva JMP, Oliveira GR, Canhestro MR, dkk. Clinical outcome of children with chronic kidney disease in a predialysis interdisciplinary program. Pediatr Nephrol 2008;23:2039-46.

6. Ahmadzadeh A, Valavi1 E, Kamali1 MZ, Ahmadzadeh A. Chronic kidney disease in Southwestern Iranian children. Iran J Pediatr 2009;19:147-53.

7. Gheissari A, Hemmatzadeh S, Merrikhi A, Tehrani SF, Madihi Y. Chronic kidney disease in children: A report from a tertiary care center over 11 years. J Nephropathology 2012;1:177-82.

8. Ardissino G, Dacco V, Testa S, Bonaudo R, Appiani AC, Taioli M, et.al. On behalf of the ItalKid Project. Epidemiology of chronic renal failure in children: data from the ItalKid Project. Pediatrics 2003;111:e382-7.

9. Hidayati EL, Trihono PP. Admission characteristics of pediatric chronic kidney disease.Paediatr Indones 2011;51:192-7.

10. Harambat J, Van Stralen KJ, Kim JJ, Tizard EJ. Epidemiology of chronic kidney disease in children. Pediatr Nephrol 2012;27:363-73.

11. Vachvanichsanong P, Dissaneewate P, McNeil E. Childhood chronic kidney disease in a developing country. Pediatr Nephrol 2008;23:1143-7.

12. Staples AO, Greenbaum LA, Smith JM, Gipson DS, Filler G, Warrady BA, dkk. Association between clinical risk factors and progression of chronic kidney disease in children. Clin J Am Soc Nephrol 2010;5:2172-9.

13. Hadtstein C, Schaefer F. Hypertension in children with chronic kidney disease: pathophysiology and management. Pediatr Nephrol 2008;23:363-71.

14. Fogo AB. Mechanisms of progression of chronic kidney disease. Pediatr Nephrol 2007;22:2011-22.

15. Mitsnefes MM. Cardiovascular complications of pediatric chronic kidney disease. Pediatr Nephrol. 2008;23:27-39.
16. Seikaly MG, Salhab N, Gipson D, Yiu V, Stablein D. Stature in children with chronic kidney disease: analysis of NAPRTCS database. Pediatr Nephrol 2006;21:793-9.

17. Wong H, Mylrea K, Feber J, Drukker A, Filler G. Prevalence of complications in children with chronic kidney disease according to KDOQI. Kidney Int 2006;70:585-90.

18. Kemkes RI. [RISKESDAS] Riset Kesehatan Dasar 2010. Jakarta: Badan Penelitian dan Pengembangan Kesehatan Kementerian Kesehatan Republik Indonesia; 2010.

19. Depkes RI. [RISKESDAS] Riset Kesehatan Dasar. Report on result of national basic health research (Riskesdas) 2007. Jakarta: Badan Penelitian dan Pengembangan Kesehatan Departemen Kesehatan Republik Indonesia; 2007.

20. Cano FJ, Valenzuela M, Zambrano P, Azoear MA, Wolff E, Delucchi MA, dkk. Renal osteodystrophy in pediatric patients on peritoneal dialysis. Advances Peritoneal Dial 2004;20:237-43.

21. Martin KJ, Gonza'lez EA. Metabolic bone disease in chronic kidney disease. J Am Soc Nephrol 2007;18:87585.

22. Hogg RJ, Furth S, Lemley KV, Portman R, Schwartz GJ, Coresh J,dkk. National Kidney Foundation's Kidney Disease Outcomes Quality Initiative clinical practice guidelines for chronic kidney disease in children and adolescents: evaluation, classification, and stratification. Pediatrics 2003;111:1416-21.

23. Wong CS, Pierce CB, Cole SR, Warady BA, Mak RHK, Benador NM, dkk. Association of proteinuria with race, cause of chronic kidney disease, and glomerular filtration rate in the chronic kidney disease in children study. Clin J Am Soc 2009;4:812-9.

24. Bhimma R, Adhikari M, Asharam K, Conno C. The spectrum of chronic kidney disease (stages 2-5) in KwaZulu-Natal, South Africa. Pediatr Nephrol 2008;23:1841-6.

25. Hiep TTM, Ismaili K, Collart F, Lombaerts RVD, Godefroid N, Ghuysen MS, dkk. Clinical characteristics and outcomes of children with stage 3-5 chronic kidney disease. Pediatr Nephrol 2010;25:935-40. 